\title{
Medical Students' Perception of the Educational Environment at College of Medicine: A Prospective Study with a Review of Literature
}

\author{
Syed Sameer Aga $\left(\mathbb{D},{ }^{1}\right.$ Muhammad Anwar Khan $\left(\mathbb{D},{ }^{2}\right.$ Mansour Al Qurashi, ${ }^{3}$ Bader Khawaji, \\ Mubarak Al-Mansour ${ }^{D},{ }^{4}$ Syed Waqas Shah, ${ }^{2}$ Amir Abushouk (D), \\ Hassan Abdullah Alabdali, ${ }^{5}$ Ahmed Sultan Alharbi, ${ }^{5}$ Mishal Essam Hawsawi, ${ }^{5}$ \\ and Osama Ali Alzharani ${ }^{5}$ \\ ${ }^{1}$ Department of Basic Medical Sciences, Quality Assurance Unit, College of Medicine, \\ King Saud Bin Abdul Aziz University for Health Sciences (KSAU-HS), \\ King Abdullah International Medical Research Centre (KAIMRC), National Guard Health Affairs (NGHA), \\ King Abdulaziz Medical City, Jeddah, Saudi Arabia \\ ${ }^{2}$ Department of Medical Education, College of Medicine, King Saud Bin Abdul Aziz University for Health Sciences (KSAU-HS), \\ King Abdullah International Medical Research Centre (KAIMRC), National Guard Health Affairs (NGHA), \\ King Abdulaziz Medical City, Jeddah, Saudi Arabia \\ ${ }^{3}$ Department of Pediatrics, Neonatology Division, National Guard Health Affairs (NGHA), \\ King Saud Bin Abdul Aziz University for Health Sciences (KSAU-HS), \\ King Abdullah International Medical Research Centre (KAIMRC), King Abdulaziz Medical City, Jeddah, Saudi Arabia \\ ${ }^{4}$ Princess Noorah Oncology Center, National Guard Health Affairs (NGHA), \\ King Saud Bin Abdul Aziz University for Health Sciences (KSAU-HS), \\ King Abdullah International Medical Research Centre (KAIMRC), King Abdulaziz Medical City, Jeddah, Saudi Arabia \\ ${ }^{5}$ Department of Basic Medical Sciences, College of Medicine, \\ King Saud Bin Abdul Aziz University for Health Sciences (KSAU-HS), \\ King Abdullah International Medical Research Centre (KAIMRC), King Abdulaziz Medical City, Jeddah, Saudi Arabia
}

Correspondence should be addressed to Syed Sameer Aga; agas@ksau-hs.edu.sa

Received 9 July 2021; Revised 1 September 2021; Accepted 8 September 2021; Published 1 October 2021

Academic Editor: Ehsan Namaziandost

Copyright (C) 2021 Syed Sameer Aga et al. This is an open access article distributed under the Creative Commons Attribution License, which permits unrestricted use, distribution, and reproduction in any medium, provided the original work is properly cited.

Dundee Ready Education Environment Measure (DREEM) inventory has been exhaustively used to evaluate the education environment (EE), especially in the health sector to identify the strengths and weaknesses of the program. This study was designed to investigate the medical students' perceptions about the education environment (EE) of the College of Medicine (COM), Jeddah. This cross-sectional study was carried out on medical students and conducted between May and August 2020. A predesigned DREEM questionnaire written in English containing five subdomains was adopted to achieve the purpose of the study. A total of 220 students responded to the dispensed survey with a mean age of $21.97(\mathrm{SD}=1.28)$. Male and female students represented $64.5 \%$ and $35.5 \%$ of the respondents, respectively, while most of them were in the fourth year of medical college $(109,49.5 \%)$, and the majority belonged to phase II (basic sciences) of the college (144,65.4\%). The overall total DREEM score for EE was 129.64 $(\mathrm{SD}=31.81 ; 64.82 \%)$, and all the five subdomains of DREEM scored above $60 \%$ with the highest score by students' academic selfperception (SASP) $(21.22 ; 66.31 \%)$ and the lowest by students' perception of learning (SPL) $(30.16 ; 62.83 \%)$. Also, SASP2 was the highest scoring item with a mean of $3.13(\mathrm{SD}=0.96)$, while SPA8 was the lowest with a mean score of $1.99(\mathrm{SD}=1.38)$. We also compared our study with the available literature for contextual interpretations. The students' assessment for EE of the medical program was positive; however, we identified a need for an improvement plan for six-weak scoring areas and one of the weak domains of DREEM i.e., students' perception of teaching (SPT). 


\section{Introduction}

In any educational institute around the world, the design, manner, and the way curriculum is implemented/imparted is regarded as the educational environment (EE) of the students. The overall learning environment not only plays an important role in students' learning and outcome but also affects their attitude, behavior, and academic progress [1-6].

With the advent of information technology, the teaching and learning environment within the universities has undergone drastic changes in the implementation of the curriculum, including the delivery of learning materials, the support of the location and tools, and assessment strategies. This transformation from the mere physical spaces and traditional lecturing to the virtual and online methods of implementing curriculum has provided the most conducive educational environment the students can ever think of, where students better accommodate their distinctive learning needs, comprehend in a better way, and acquire the latest knowledge and skills that are necessarily essential for them to withstand the enormous competition in the medical market $[5,7,8]$.

EE of any institution comprises of several controllable and conditioned factors which are known to influence the overall process of teaching and learning and modulates the learners' perspectives about the infrastructure, availability of facilities, teaching methodology, interpersonal relationships, cultural compliance of the university, and curriculum. It is a holistic climatic idea that encompasses three essential levels of the educational institution-the classroom, department, and the institution [9]. A well-suited EE is reported to enhance various competencies of the medicine students such as self-confidence, critical thinking, achievement, motivation, behavior, independence, and psychosocial wellbeing [10].

For the evaluation of any medical education program, the assessment of EE is considered as one of the major areas by the World Federation for Medical Education [11, 12]. Dundee Ready Education Environment Measure (DREEM) inventory has been exhaustively used to evaluate EE, especially in the health sector in order to identify the strengths and weaknesses of the program, to develop the improvement plans to foster excellent quality of education, to compare students in different study years in college, to provide medical educators an inclusive view of the delivered curriculum, and to help in modifying the curriculum by comparing past and present one and in evaluating the efficacy of a university program in context to their peers $[5,6,8,13,14]$.

A number of studies have been carried out around the globe, in almost all continents, in countries such as Spain, UK, Pakistan, India, Iran, Aruba, Malaysia, Thailand, and Nepal [5, 9, 13, 15-23], using the DREEM questionnaire since its inception in 1997 [24], including Middle Eastern countries [25-31], as well as the Kingdom of Saudi Arabia [1, 32-39] (Table 1, detailed review of literature of DREEM studies and their description and results).
In the Kingdom of Saudi Arabia, a change from the traditional curriculum to a PBL-based hybrid is going on. This is to achieve better implementation of curriculum for effective and conducive teaching and learning environment. Therefore, a gap exists in the literature for the perception of students about the PBL-based educational environment, for which only a few studies have been carried out. Hence, we designed the present study to investigate the medical students' perceptions about the education environment (EE) of the College of Medicine (COM), Jeddah. Furthermore, the study would help us to compare the students' perceptions according to the demographic characteristics enabling us to identify the strengths and weaknesses of the COM curriculum and to compare the scores with other medical colleges within or outside the kingdom.

The investigation aimed to answer/know the following four questions.

(1) What is the perception of medical students towards the learning/teaching environment in COM, KSAUHS in Jeddah campus?

(2) Whether there is any difference between the perceptions of students according to the stages of medical education, i.e., the phase II (preclinical) and phase III (clinical stages)

(3) What are the perceived strengths and weaknesses of our medicine program?

(4) What is the medical students' perception towards five domains of the DREEM questionnaire? which are as follows:
(a) Perception of learning
(b) Perception of teachers
(c) Academic self-perception
(d) Perception of atmosphere
(e) Social self-perception

\section{Methods}

2.1. Study Settings. This study is a descriptive type of research using a survey approach. The study was carried in between May and August 2020. All students were selected using the convenience sampling method. The study was approved by the Institutional Ethic and Research Board (IRB) of King Saud bin Abdulaziz University for Health Sciences (KSAU-HS) and King Abdullah International Medical Research Center (KAIMRC).

2.2. Sample Size. This study was carried out on the Medical Students of King Saud bin Abdulaziz University for Health Sciences (KSAU-HS) and National Guard Health Affairs, Jeddah Campus, Saudi Arabia.

Sample size was calculated by using the Raosoft ${ }^{\circledR}$ software (website link: https://www.raosoft.com/samplesize. html). The required sample size was calculated at the $90 \%$ confidence level with an estimated $50 \%$ prevalence of awareness regarding euthanasia and a margin of error $\pm 5 \%$. 
TABLE 1: Comparison of DREEM mean total scores of different studies in various countries.

\begin{tabular}{|c|c|c|c|c|}
\hline Country & Year of report & Number of participants & Overall DREEM score & Reference \\
\hline \multicolumn{5}{|l|}{ Within Kingdom } \\
\hline Saudi Arabia & 2004 & 450 & 102 & {$[2]$} \\
\hline Saudi Arabia & 2008 & 500 & 89.9 & {$[4]$} \\
\hline Saudi Arabia & 2012 & 358 & 108.28 & [39] \\
\hline Saudi Arabia & 2012 & 100 & 112.95 & [40] \\
\hline Saudi Arabia & 2012 & 100 & 143.9 & {$[38]$} \\
\hline Saudi Arabia & 2013 & 573 & 106 & {$[36]$} \\
\hline Saudi Arabia & 2013 & 524 & 120.70 & {$[37]$} \\
\hline Saudi Arabia & 2013 & 76 & 96.57 & {$[41]$} \\
\hline Saudi Arabia & 2013 & 454 & 112 & {$[42]$} \\
\hline Saudi Arabia & 2014 & 707 & 106.55 & {$[43]$} \\
\hline Saudi Arabia & 2016 & 279 & 124.90 & {$[44]$} \\
\hline Saudi Arabia & 2017 & 221 & 101.65 & {$[34]$} \\
\hline Saudi Arabia & 2017 & 62 & $171.57 / 250$ & {$[35]$} \\
\hline Saudi Arabia & 2017 & 714 & 111 & {$[45]$} \\
\hline Saudi Arabia & 2018 & 302 & 108.42 & {$[46]$} \\
\hline Saudi Arabia & 2019 & 518 & 112.38 & {$[1]$} \\
\hline Saudi Arabia & 2019 & 242 & 129.70 & {$[8]$} \\
\hline Saudi Arabia & 2019 & 121 & 126.4 & {$[33]$} \\
\hline Saudi Arabia & 2020 & 217 & 125 & {$[32]$} \\
\hline \multicolumn{5}{|l|}{ Middle East } \\
\hline United Arab Emirates & 2011 & 190 & 120 & [29] \\
\hline Kuwait & 2009 & 202 & 105 & {$[47]$} \\
\hline Kuwait & 2015 & 117 & 108.7 & {$[28]$} \\
\hline Oman & 2018 & 737 & 130.75 & {$[31]$} \\
\hline Egypt & 2017 & 677 & 118.4 & {$[27]$} \\
\hline Egypt & 2015 & 511 & 112.65 & {$[48]$} \\
\hline Turkey & 2008 & 553 & 117.63 & {$[30]$} \\
\hline Iran & 2010 & 210 & 99.6 & {$[5]$} \\
\hline Iran & 2015 & 60 & 95.8 & {$[49]$} \\
\hline Iran & 2013 & 202 & 114.3 & {$[50]$} \\
\hline Iran & 2015 & 493 & 113.5 & {$[20]$} \\
\hline Sudan & 2018 & 638 & 122 & {$[25]$} \\
\hline Sudan & 2018 & 347 & 125.29 & {$[26]$} \\
\hline \multicolumn{5}{|l|}{ Asia } \\
\hline Pakistan & 2019 & 1185 & 89.23 & {$[18]$} \\
\hline Pakistan & 2019 & 435 & 110.72 & {$[18]$} \\
\hline Pakistan & 2018 & 442 & 129.92 & [9] \\
\hline Pakistan & 2018 & 884 & 126 & {$[9]$} \\
\hline Pakistan & 2017 & 416 & 125.77 & {$[21]$} \\
\hline Pakistan & 2016 & 180 & 116.13 & {$[10]$} \\
\hline Pakistan & 2015 & 2084 & 105 & [13] \\
\hline India & 2013 & 348 & 101.13 & {$[16]$} \\
\hline India & 2013 & 73 & 131.79 & [19] \\
\hline India & 2016 & 322 & 123 & {$[51]$} \\
\hline India & 2019 & 55 & 119 & {$[52]$} \\
\hline Nepal & 2019 & 325 & 122 & [53] \\
\hline Nepal & 2019 & 122 & 131.25 & [23] \\
\hline Malaysia & 2009 & 71 & 133.12 & {$[54]$} \\
\hline Malaysia & 2015 & 190 & 127.9 & [21] \\
\hline Malaysia & 2014 & 438 & 125.3 & {$[55]$} \\
\hline Philippines & 2016 & 341 & 120.38 & {$[56]$} \\
\hline Thailand & 2018 & 2,467 & 131.1 & {$[22]$} \\
\hline Sri Lanka & 2005 & 339 & 108 & [57] \\
\hline Japan & 2010 & 6725 & 112 & {$[58]$} \\
\hline Korea & 2019 & 239 & 117.5 & [59] \\
\hline \multicolumn{5}{|l|}{ Europe } \\
\hline Germany & 2011 & 1119 & 109.75 & {$[60]$} \\
\hline Sweden & 2011 & 503 & 145.2 & {$[61]$} \\
\hline United Kingdom & 2009 & 216 & 143.3 & {$[62]$} \\
\hline
\end{tabular}


TABLE 1: Continued.

\begin{tabular}{|c|c|c|c|c|}
\hline Country & Year of report & Number of participants & Overall DREEM score & Reference \\
\hline United Kingdom & 2007 & 130 & 143 & [63] \\
\hline United Kingdom & 2007 & 206 & 139 & {$[15]$} \\
\hline Ireland & 2010 & 199 & 149.47 & {$[64]$} \\
\hline Spain & 2015 & 894 & 116.2 & {$[65]$} \\
\hline Spain & 2015 & 619 & 104.8 & {$[65]$} \\
\hline \multicolumn{5}{|l|}{ Others } \\
\hline Canada & 2004 & 407 & 97 & {$[66]$} \\
\hline Chile & 2009 & 328 & 127.5 & {$[67]$} \\
\hline Australia & 2009 & 143 & 62 & {$[68]$} \\
\hline Australia & 2019 & 192 & 127 & [69] \\
\hline
\end{tabular}

With a total student population of 800 at College of Medicine (COM), Jeddah; the necessary sample size was calculated to be 203 . However, the final sample size of 220 was deemed the best representation of the study population (to account for nonresponse rate). Following a clear instruction and mentioning the objectives of the study, an informed consent from all the participants was taken (first question on an online portal) for the implementation of a predesigned DREEM questionnaire.

\subsection{Dundee Ready Education Environment Measure} (DREEM). The DREEM is a survey tool developed to quantitatively measure student's perceptions of their learning environment within a health profession educational setting and has been exhaustively used to collect evidence about the educational environment (EE) across the globe (Table 1).

The DREEM survey consists of 50 items or statements, each of which is scored $0-4$ on a 5-point Likert scale $(0=$ strongly disagree to $4=$ strongly agree) [14]. However, there are nine negatively stated items (questions 4, 8, 9, 17, $25,35,39,48$, and 50) which are scored in reverse ( $0=$ strongly agree to $4=$ strongly disagree); thus, after correction, higher scores indicate disagreement with that item. The DREEM questionnaire was developed at the University of Dundee to assess five domains of EE $[14,24]$ (Table 2).

(1) Students' perceptions of learning (SPL) (12 items, maximum score 48)

(2) Students' perceptions of faculty (SPT) (11 items, maximum score 44)

(3) Students' academic self-perceptions (SASP) (8 items, maximum score 32)

(4) Students' perceptions of atmosphere (SPA) (12 items, maximum score 48) and

(5) Students' social self-perceptions (SSSP) (7 items, maximum score 28)

Mean scores for individual items are calculated with a maximum score of 4.0 for each item. Items with a mean score of $\geq 3.5$ are true positive points, and those with a mean of $\leq 2$ are problem areas; scores in between these two limits indicate aspects of the environment that need to be enhanced. An overall or composite score is obtained by summing the mean score for each subscale, with a maximum possible score of 200, and the global scores are interpreted as follows: $0-50=$ very poor; $51-100=$ many problems; $101-150=$ more positive than negative; $151-200=$ excellent $[5,6,14,24]$.

2.4. Data Collection and Statistical Analysis. The data from the students were collected via an online survey using the Google Forms platform. The questionnaire was sent to all medical students via their official e-mail by the Students Affairs Departments of the College, Jeddah campus. The data collected were tabulated, and analysis was performed using IBM Statistic SPSS (SPSS Inc., Chicago, IL, USA) version 20.0. Descriptive analysis was employed to sum up the dataset; numerical variables were described using means and standard deviations (SD), and categorical variables were presented in frequencies and percentages. To test the influence of demographic characteristics on knowledge and attitude, chi-square or Fishers exact tests were applied wherever suitable, and $p$ values were obtained for each test. $P$ values less than 0.05 were accepted as statistically significant. The Independent $t$-test was applied for comparison between two means variables, which included sex, phase of the study, and type of secondary school. Analysis of variance (ANOVA) was used for comparison of more than two means, which included gender, education phase, and year of study. Multivariate logistic regression models were used to identify the factors related to education environment perception that differ between students.

\section{Results}

3.1. Participants. The demographic data of the participants are given in Table 3. A total of 220 students participated in this study. The mean age of the participants was 21.97 $(\mathrm{SD}=1.28)$. Male and female students represented $64.5 \%$ and $35.5 \%$ of the respondents, respectively; while, $97.3 \%$ of respondents were single (214/220). Most of the participating students were in the fourth year of medical college (109, $49.5 \%)$, followed by the fifth year $(49,22.3 \%)$, and most belonged to phase II (basic sciences) of the college (144, $65.4 \%)$. 
TABLE 2: Guide of DREEM score categories and interpretation according to domain.

\begin{tabular}{|c|c|c|}
\hline Domain measured & Overall score & Reflective interpretation \\
\hline Students' perception of learning (SPL) & $\begin{array}{c}0-12 \\
13-24 \\
25-36 \\
37-48\end{array}$ & $\begin{array}{l}\text { Very poor } \\
\text { Teaching is viewed negatively } \\
\text { A more positive approach* } \\
\text { Teaching highly thought of }\end{array}$ \\
\hline Students' perception of teachers (SPT) & $\begin{array}{c}0-11 \\
12-22 \\
23-33 \\
34-44\end{array}$ & $\begin{array}{c}\text { Abysmal } \\
\text { In need of some retraining } \\
\text { Moving in the right direction* } \\
\text { Model teachers }\end{array}$ \\
\hline Students' academic self-perception (SASP) & $\begin{array}{c}0-8 \\
9-16 \\
17-24 \\
25-32 \\
\end{array}$ & $\begin{array}{c}\text { Feeling of total failure } \\
\text { Many negative aspects } \\
\text { Feeling more on the positive side* } \\
\text { Confident }\end{array}$ \\
\hline Students' perception of atmosphere (SPA) & $\begin{array}{c}0-12 \\
13-24 \\
25-36 \\
37-48\end{array}$ & $\begin{array}{c}\text { A terrible environment } \\
\text { There are many issues that need change } \\
\text { A more positive atmosphere* } \\
\text { A good feeling overall }\end{array}$ \\
\hline Students' social self-perceptions (SSSP) & $\begin{array}{c}0-7 \\
8-14 \\
15-21 \\
22-28\end{array}$ & $\begin{array}{c}\text { Miserable } \\
\text { Not a nice place } \\
\text { Not too bad* } \\
\text { Very good socially }\end{array}$ \\
\hline
\end{tabular}

DREEM, Dundee Ready Education Environment Measure. * Our study scores for the DREEM subdomains. The bold numbers represent the scales within which the results of the current study fall.

TABle 3: Demographic characteristics of student respondents.

\begin{tabular}{lcc}
\hline Age & Mean & SD \\
& 21.97 & 1.28 \\
& $n$ & \\
\hline Gender & & \\
Male & 142 & 64.5 \\
Female & 78 & 35.5 \\
\hline Marital status & & \\
Single & 214 & 97.3 \\
Married & 4 & 1.8 \\
Divorced & 2 & 0.9 \\
\hline Academic level & & \\
Third year & 35 & 15.9 \\
Fourth year & 109 & 49.5 \\
Fifth year & 49 & 22.3 \\
Sixth year & 27 & 12.3 \\
\hline Phase & & \\
Phase II & 144 & 65.5 \\
Phase III & 76 & 100 \\
Total & 220 & \\
\hline
\end{tabular}

3.2. Overall DREEM Scores. The overall total score for the student's perceptions of the educational environment was found to be 129.64 ( $\mathrm{SD}=31.81 ; 64.82 \%)$. Figure 1 shows the graphical representation of the overall DREEM scores versus the mean scores of the five subdomains. All of the five subdomains of DREEM scored above $60 \%$, with the highest score by SASP (66.31\%) and lowest by SPL (62.83\%). Figure 2 shows the mean DREEM scores as per the demographic characteristics of the participants (Table 4).

3.3. Students' Perception of Learning (SPL). In this subdomain constituting of 12 items (SPL1-12), a total score of
$30.16(\mathrm{SD}=8.95 ; 62.83 \%)$ was recorded (Table 4; Figure 1$)$, however, when differentiated based upon the phases of education scores differed significantly (phase II $=28.97$ vs. phase III $=32.42 ; p<0.05$ ). Only one item of this subdomain scored near to two, "SPL1-I am encouraged to participate in teaching sessions/class" which had a mean score of 2.01 $(\mathrm{SD}=1.46)$; furthermore, out of 12 items, only three differed significantly $(p<0.05)$ in their phase-wise total scores, "SPL1-I am encouraged to participate in teaching sessions/ class," "SPL6-The teaching helps to develop my confidence," and "SPL12-The teaching is too teacher-centered" (Table 5).

3.4. Students' Perception of Teachers (SPT). In this subdomain constituting of 11 items (SPT1-11), a total score of 28.51 ( $\mathrm{SD}=7.77 ; 64.79 \%)$ was recorded (Table 4; Figure 1), and the scores based upon phases of education also differed significantly (phase II $=27.34$ vs. phase III $=30.72 ; p<0.05$ ). Additionally, two items of this subdomain scored near to two, "SPT3-The teachers ridicule the students" with a mean score of 2.05 ( $\mathrm{SD}=1.35)$ and "SPT9-The teachers get angry in class" with a mean score of $2.03(\mathrm{SD}=1.41)$, and one item had a high mean score of $3.08(\mathrm{SD}=1.15)$, "SPT1-The teachers are knowledgeable" (Table 6). Also, out of 11 items, four differed significantly $(p<0.05)$ in their phase-wise total scores "SPT3-The teachers ridicule the students," "SPT6-The teachers are good at providing feedback to students," "SPT9The teachers get angry in class," and "SPT11-The students irritate the teachers" (Table 5). SPT11 mean scores also differed significantly in between gender $(p<0.05)$.

3.5. Students' Academic Self-Perception (SASP). In this subdomain constituting of 8 items (SASP1-8), a total score of $21.22(\mathrm{SD}=5.91 ; 66.31 \%)$ was recorded (Table 4; Figure 1 ), 


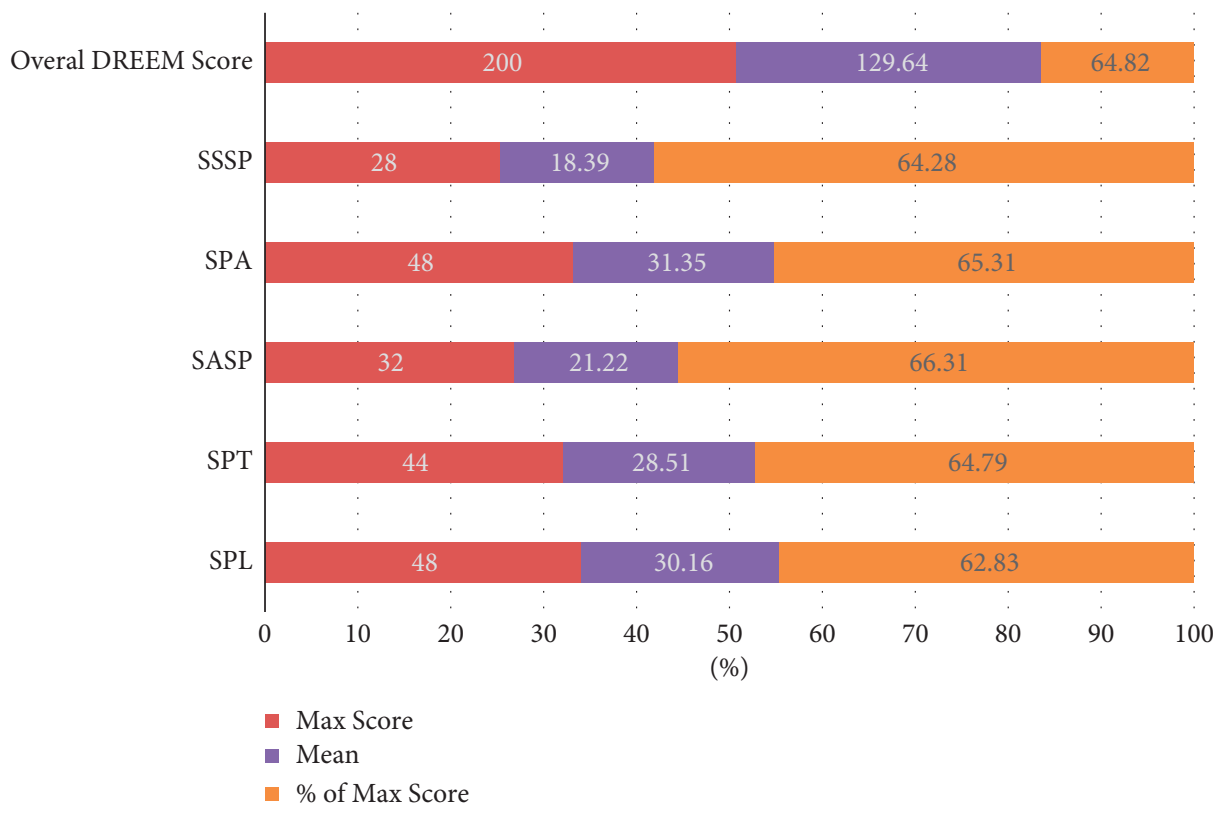

FIGURE 1: Diagram showing the comparisons between maximum achievable scores in the DREEM questionnaire and actual achieved scores in five domains.

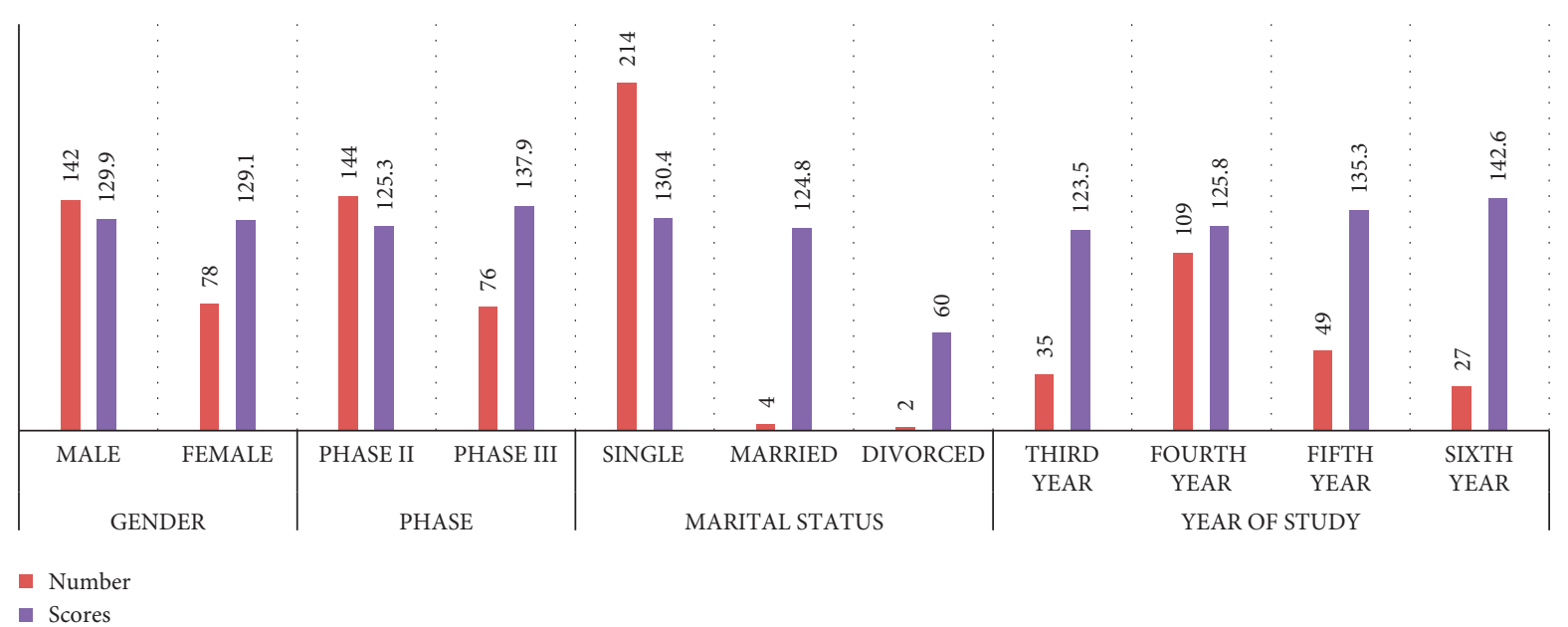

FIGURE 2: Diagram showing the scores in the DREEM questionnaire as per the demographic characteristics of participants.

and the scores based upon phases of education also differed significantly (phase II $=20.49$ vs. phase III $=22.60 ; p<0.05$ ); however, with scores ranging between 2.20 and 3.13 for all items, one item "SASP2-I am confident about passing this year" scored with a mean of $3.13(\mathrm{SD}=0.96)$, which made it the highest scoring item in this survey. However, also, out of eight items, three differed significantly $(p<0.05)$ in their phase-wise total scores "SASP3-I feel I am being well prepared for my profession," "SASP4-Last year's work has been a good preparation for this year's work," and "SASP5 I am able to memorize all I need" (Table 5).

3.6. Students' Perception of Atmosphere (SPA). In this subdomain constituting of 12 items (SPA1-12), a total score of $31.35(\mathrm{SD}=8.45 ; 65.31 \%$ ) was recorded (Table 4; Figure 1), and the total scores based upon phases of education also differed significantly (phase $\mathrm{II}=30.22$ vs. phase $\mathrm{III}=33.50$; $p<0.05)$. However, one item of this subdomain scored below two, i.e., "SPA8-I find the experience disappointing" with a score of $1.99(\mathrm{SD}=1.38)$, which is the lowest of all fifty items of DREEM. Additionally, in this domain, $50 \%$ of the items differed significantly $(p<0.05)$ in their phase-wise total scores (Tables 5 and 6).

3.7. Students' Social Self-Perceptions (SSSP). In this subdomain constituting of 7 items (SSSP1-7), a total score of $18.39(\mathrm{SD}=4.84 ; 64.28 \%)$ was recorded (Table 4; Figure 1), with no differences in between genders and phases of education. Also, one item of this subdomain scored above three, i.e., "SSSP4-I have good friends in this program/ course" with a score of $3.12(\mathrm{SD}=1.00)$, which is the second highest scoring item in this study (Tables 5-7). 
TABLE 4: Mean (SD) DREEM scores as per demographic characteristics of the participants.

\begin{tabular}{|c|c|c|c|c|c|c|c|c|c|c|c|c|c|}
\hline \multirow{3}{*}{ Variable } & \multirow{3}{*}{$\begin{array}{c}n \\
200\end{array}$} & \multicolumn{12}{|c|}{ Mean (SD) } \\
\hline & & \multicolumn{2}{|c|}{ Overall } & \multicolumn{2}{|c|}{ SPL } & \multicolumn{2}{|c|}{ SPT } & \multicolumn{2}{|c|}{ SASP } & \multicolumn{2}{|c|}{ SPA } & \multicolumn{2}{|c|}{ SSSP } \\
\hline & & 129.64 & 31.81 & 30.16 & 8.95 & 28.51 & 7.77 & 21.22 & 5.91 & 31.35 & 8.47 & 18.39 & 4.84 \\
\hline \multicolumn{14}{|l|}{ Gender } \\
\hline Male & 142 & 129.9 & 29.6 & 29.6 & 8.7 & 28.5 & 7.1 & 21.5 & 5.5 & 31.8 & 8.0 & 18.5 & 4.6 \\
\hline Female & 78 & 129.1 & 35.7 & 31.3 & 9.4 & 28.4 & 8.9 & 20.7 & 6.6 & 30.6 & 9.3 & 18.1 & 5.3 \\
\hline \multicolumn{14}{|l|}{ Phase } \\
\hline Phase II & 144 & 125.3 & 28.7 & 29.0 & 8.3 & 27.3 & 7.2 & 20.5 & 5.6 & 30.2 & 7.9 & 18.3 & 4.2 \\
\hline Phase III & 76 & 137.9 & 35.7 & 32.4 & 9.7 & 30.7 & 8.3 & 22.6 & 6.3 & 33.5 & 9.2 & 18.7 & 5.8 \\
\hline \multicolumn{14}{|l|}{ Marital status } \\
\hline Single & 214 & 130.4 & 31.1 & 30.3 & 8.8 & 28.7 & 7.6 & 21.3 & 5.8 & 31.6 & 8.3 & 18.4 & 4.8 \\
\hline Married & 4 & 124.8 & 10.5 & 30.0 & 2.9 & 26.5 & 4.9 & 20.3 & 2.2 & 29.3 & 5.0 & 18.7 & 0.5 \\
\hline Divorced & 2 & 60.0 & 72.1 & 11.0 & 14.1 & 13.0 & 18.4 & 10.0 & 14.1 & 14.0 & 19.8 & 12.0 & 5.6 \\
\hline \multicolumn{14}{|l|}{ Year of study } \\
\hline Third year & 35 & 123.5 & 26.2 & 28.9 & 7.2 & 26.5 & 7.3 & 19.7 & 6.1 & 29.9 & 7.6 & 18.5 & 3.5 \\
\hline Fourth year & 109 & 125.8 & 29.6 & 29.0 & 8.7 & 27.6 & 7.2 & 20.8 & 5.4 & 30.3 & 8.0 & 18.1 & 4.4 \\
\hline Fifth year & 49 & 135.3 & 37.4 & 31.4 & 10.6 & 30.4 & 8.7 & 22.4 & 6.4 & 32.8 & 9.9 & 18.3 & 6.0 \\
\hline Sixth year & 27 & 142.6 & 32.5 & 34.3 & 7.5 & 31.2 & 7.6 & 23.0 & 6.3 & 34.9 & 7.7 & 19.2 & 5.5 \\
\hline
\end{tabular}

The bold numbers represent the overall scores of the DREEM tool, as per the demographics of the participants.

TABLE 5: Mean (SD) DREEM scores of the domains differentiated as per gender and phase of education.

\begin{tabular}{|c|c|c|c|c|c|c|c|c|c|c|c|c|}
\hline & \multicolumn{2}{|c|}{$\begin{array}{c}\text { Overall } \\
(n=220)\end{array}$} & \multicolumn{2}{|c|}{$\begin{array}{c}\text { Male } \\
(n=142)\end{array}$} & \multicolumn{2}{|c|}{$\begin{array}{l}\text { Female } \\
(n=78)\end{array}$} & \multirow{2}{*}{$\begin{array}{c}P \\
\text { value }\end{array}$} & \multicolumn{2}{|c|}{$\begin{array}{l}\text { Phase II } \\
(n=144)\end{array}$} & \multicolumn{2}{|c|}{$\begin{array}{c}\text { Phase III } \\
(n=76)\end{array}$} & \multirow{2}{*}{$\begin{array}{c}P \\
\text { value }\end{array}$} \\
\hline & Mean & $\mathrm{SD}$ & Mean & SD & Mean & $\mathrm{SD}$ & & Mean & $\mathrm{SD}$ & Mean & $\mathrm{SD}$ & \\
\hline Students' perception of learning (total) & 30.16 & 8.95 & 29.56 & 8.68 & 31.26 & 9.37 & 0.180 & 28.97 & 8.33 & 32.42 & 9.67 & 0.006 \\
\hline $\begin{array}{l}\text { SPL1. I am encouraged to participate in } \\
\text { teaching sessions/class }\end{array}$ & 2.01 & 1.46 & 1.94 & 1.443 & 2.13 & 1.480 & 0.370 & 1.85 & 1.426 & 2.32 & 1.472 & 0.023 \\
\hline SPL2. The teaching is often stimulating & 2.69 & 1.16 & 2.68 & 1.146 & 2.72 & 1.205 & 0.799 & 2.66 & 1.141 & 2.75 & 1.212 & 0.586 \\
\hline SPL3 The teaching is student-centered & 2.75 & 0.99 & 2.75 & 1.014 & 2.77 & 0.966 & 0.872 & 2.72 & .994 & 2.83 & .999 & 0.422 \\
\hline $\begin{array}{l}\text { SPL4. The teaching helps to develop my } \\
\text { competence }\end{array}$ & 2.66 & 1.07 & 2.63 & 1.075 & 2.71 & 1.058 & 0.636 & 2.58 & 1.048 & 2.80 & 1.096 & 0.148 \\
\hline SPL5. The teaching is well focused & 2.57 & 1.15 & 2.50 & 1.135 & 2.71 & 1.186 & 0.208 & 2.48 & 1.200 & 2.75 & 1.047 & 0.085 \\
\hline $\begin{array}{l}\text { SPL6. The teaching helps to develop my } \\
\text { confidence }\end{array}$ & 2.49 & 1.20 & 2.49 & 1.195 & 2.49 & 1.225 & 0.994 & 2.31 & 1.231 & 2.83 & 1.076 & 0.001 \\
\hline SPL7. The teaching time is put to good use & 2.40 & 1.25 & 2.30 & 1.249 & 2.59 & 1.242 & 0.104 & 2.24 & 1.274 & 2.72 & 1.150 & 0.006 \\
\hline $\begin{array}{l}\text { SPL8. The teaching over emphasizes } \\
\text { factual learning }\end{array}$ & 2.62 & 1.11 & 2.61 & 1.103 & 2.64 & 1.116 & 0.856 & 2.56 & 1.102 & 2.75 & 1.109 & 0.216 \\
\hline $\begin{array}{l}\text { SPL9. I am clear about the learning } \\
\text { objectives of the course }\end{array}$ & 2.72 & 1.17 & 2.62 & 1.225 & 2.90 & 1.052 & 0.079 & 2.67 & 1.217 & 2.80 & 1.083 & 0.422 \\
\hline $\begin{array}{l}\text { SPL10. The teacher encourages me to be } \\
\text { an active learner }\end{array}$ & 2.58 & 1.12 & 2.49 & 1.135 & 2.73 & 1.077 & 0.132 & 2.49 & 1.128 & 2.75 & 1.085 & 0.096 \\
\hline $\begin{array}{l}\text { SPL11. Long-term learning is emphasized } \\
\text { over short-term learning }\end{array}$ & 2.52 & 1.20 & 2.47 & 1.189 & 2.60 & 1.231 & 0.442 & 2.48 & 1.212 & 2.59 & 1.191 & 0.509 \\
\hline $\begin{array}{l}\text { SPL12. The teaching is too teacher- } \\
\text { centered }\end{array}$ & 2.15 & 1.29 & 2.08 & 1.289 & 2.28 & 1.288 & 0.261 & 1.95 & 1.253 & 2.53 & 1.280 & 0.002 \\
\hline Students' perception of teachers (total) & 28.51 & 7.77 & 28.55 & 7.10 & 28.43 & 8.90 & 0.918 & 27.34 & 7.24 & 30.72 & 8.28 & 0.002 \\
\hline SPT1. The teachers are knowledgeable & 3.08 & 1.15 & 3.10 & 1.027 & 3.05 & 1.347 & 0.788 & 3.04 & 1.200 & 3.16 & 1.046 & 0.476 \\
\hline $\begin{array}{l}\text { SPT2. The teachers espouse a patient- } \\
\text { centered approach to teaching }\end{array}$ & 2.92 & 0.97 & 2.94 & 0.939 & 2.90 & 1.027 & 0.775 & 2.94 & .952 & 2.88 & 1.006 & 0.648 \\
\hline SPT3. The teachers ridicule the students & 2.05 & 1.35 & 2.00 & 1.342 & 2.13 & 1.361 & 0.501 & 1.85 & 1.366 & 2.42 & 1.236 & 0.002 \\
\hline SPT4. The teachers are authoritarian & 2.43 & 1.20 & 2.42 & 1.144 & 2.45 & 1.306 & 0.845 & 2.26 & 1.245 & 2.75 & 1.047 & 0.002 \\
\hline $\begin{array}{l}\text { SPT5. The teachers have good } \\
\text { communication skills with patients }\end{array}$ & 2.85 & 0.99 & 2.84 & 0.950 & 2.88 & 1.057 & 0.739 & 2.81 & 1.033 & 2.95 & .893 & 0.312 \\
\hline $\begin{array}{l}\text { SPT6. The teachers are good at providing } \\
\text { feedback to students }\end{array}$ & 2.64 & 1.10 & 2.54 & 1.102 & 2.81 & 1.070 & 0.086 & 2.51 & 1.177 & 2.88 & .879 & 0.008 \\
\hline
\end{tabular}


TABle 5: Continued.

\begin{tabular}{|c|c|c|c|c|c|c|c|c|c|c|c|c|}
\hline & \multicolumn{2}{|c|}{$\begin{array}{c}\text { Overall } \\
(n=220)\end{array}$} & \multicolumn{2}{|c|}{$\begin{array}{c}\text { Male } \\
(n=142)\end{array}$} & \multicolumn{2}{|c|}{$\begin{array}{l}\text { Female } \\
(n=78)\end{array}$} & \multirow{2}{*}{$\begin{array}{c}P \\
\text { value }\end{array}$} & \multicolumn{2}{|c|}{$\begin{array}{l}\text { Phase II } \\
(n=144)\end{array}$} & \multicolumn{2}{|c|}{$\begin{array}{c}\text { Phase III } \\
(n=76)\end{array}$} & \multirow{2}{*}{$\begin{array}{c}P \\
\text { value }\end{array}$} \\
\hline & Mean & SD & Mean & $\mathrm{SD}$ & Mean & SD & & Mean & SD & Mean & SD & \\
\hline $\begin{array}{l}\text { PT7. The teachers provide constructive } \\
\text { iticism here }\end{array}$ & 58 & 1.11 & 57 & 1.020 & 2.59 & 263 & 908 & 2.53 & 1.176 & 2.66 & .974 & 408 \\
\hline SPT8. The teachers give clear examples & 2.81 & 1.11 & 2.74 & 1.109 & 2.94 & 997 & 0.208 & 2.73 & 1.117 & 2.96 & .076 & 0.141 \\
\hline SPT9. The teachers get angry in class & 03 & 141 & 2.15 & 1431 & 1.81 & 349 & 0.080 & 1.79 & .379 & 2.49 & .361 & 0.001 \\
\hline SPT10. The teachers are well prepared $\mathrm{f}$ & 2.81 & 1.05 & 2.80 & 1.021 & 2.85 & .094 & 0.733 & 2.83 & 1.017 & 2.78 & .103 & 0.701 \\
\hline SPT11. The students irritate the teachers & 2.31 & 1.32 & 2.46 & 1.270 & 2.04 & 372 & 24 & 2.05 & 276 & 2.80 & 265 & $<0.001$ \\
\hline Students' academic self-perception (total) & 2122 & 501 & 21.51 & & 20.69 & 6.56 & & 20.49 & 5.56 & 22.60 & 6.33 & 0.011 \\
\hline $\begin{array}{l}\text { SASP1. Learning strategies which worked } \\
\text { for me before, continue to work for me } \\
\text { now }\end{array}$ & 2.55 & .29 & 63 &  & 38 & 461 & & 54 & & 2.55 & 26 & \\
\hline & 3.13 & 0.96 & 3.24 & .930 & 92 & .990 & 019 & 3.15 & .931 & 3.09 & .022 & 694 \\
\hline & .44 & 1.16 & 2.44 & .133 & 44 & 212 & .996 & 2.26 & 1.157 & 2.78 & .091 & .001 \\
\hline & 54 & 111 & 2.56 & 105 & .51 & .181 & 780 & 2.38 & .128 & 2.84 & .981 & .002 \\
\hline $1 \mathrm{I}$ need & & & & & & & & & & 259 & 6 & \\
\hline & 267 & 10 & 2.68 & 076 & 2.65 & 115 & 5 & 58 & 119 & 2.83 & .012 & 1 \\
\hline & 76 & 11 & 80 & م & .68 & 157 & 430 & 66 & 135 & 95 & .031 & 059 \\
\hline & ot & 0.98 & 89 & & .06 & 73 & & .94 & 040 & .97 & 032 & 4 \\
\hline & & & & & & & & & & & & \\
\hline & 292 & 1 & 3.06 & .037 & 2.67 & 374 & .031 & 2.97 & .179 & 2.83 & .182 & .416 \\
\hline SPA2. T & & & & & & & & & & 74 & 136 & \\
\hline & 13 & .37 & .21 & 309 & 1.99 & 481 & .266 & 1.92 & .412 & 2.54 & .205 & .001 \\
\hline & .71 & 1.12 & 2.61 & 1.129 & 2.88 & 093 & 0.085 & 2.64 & 1.210 & 2.84 & .925 & .166 \\
\hline es for me to & 2.75 & 1 & .76 & 1 & 274 & 122 & 914 & 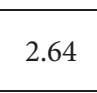 & .210 & 2.97 & 864 & 019 \\
\hline & & & & & & & & & & & & \\
\hline during & 70 & 1 & 2.74 & 1 & 2.78 & 158 & & .72 & 1.161 & 2.82 & .055 & .558 \\
\hline & & & & & & & & & & & & \\
\hline & & & 2.80 & & & & & & & 2.96 & .051 & 0.026 \\
\hline SPA10. The enjoyment & 2.35 & 1.29 & .41 & & .20 & 353 & & 17 & .308 & 2.70 & .178 & .003 \\
\hline $\begin{array}{l}\text { SPA } \\
\text { learn }\end{array}$ & 2.72 & 1.12 & 75 & 1.133 & 67 & 089 & & .61 & 1.153 & 2.92 & .017 & .042 \\
\hline 2. I feel able to ask the questions I & 270 & 1 & 2.75 & 168 & 2.60 & 220 & 0.368 & 2.65 & 260 & 2.80 & .033 & 0.323 \\
\hline & & & & & & & & & & & & \\
\hline $\mathrm{m}$ for & 2.59 & 1.3 & 2.60 & 120 & 2.56 & 1.456 & 0 & ? & 1.300 & 2.51 & .381 & .553 \\
\hline $\begin{array}{l}\text { SS } \\
\text { pr }\end{array}$ & 2.55 & 1.1 & 2.01 & 1.091 & 2.46 & 1.136 & 0.357 & 2.50 & 1.008 & 2.51 & 1.281 & 0.709 \\
\hline
\end{tabular}


TABLE 5: Continued.

\begin{tabular}{|c|c|c|c|c|c|c|c|c|c|c|c|c|}
\hline & \multicolumn{2}{|c|}{$\begin{array}{c}\text { Overall } \\
(n=220)\end{array}$} & \multicolumn{2}{|c|}{$\begin{array}{c}\text { Male } \\
(n=142)\end{array}$} & \multicolumn{2}{|c|}{$\begin{array}{l}\text { Female } \\
(n=78)\end{array}$} & \multirow{2}{*}{$\begin{array}{c}P \\
\text { value }\end{array}$} & \multicolumn{2}{|c|}{$\begin{array}{l}\text { Phase II } \\
(n=144)\end{array}$} & \multicolumn{2}{|c|}{$\begin{array}{c}\text { Phase III } \\
(n=76)\end{array}$} & \multirow{2}{*}{$\begin{array}{c}P \\
\text { value }\end{array}$} \\
\hline & Mean & $\mathrm{SD}$ & Mean & SD & Mean & SD & & Mean & SD & Mean & $\mathrm{SD}$ & \\
\hline $\begin{array}{l}\text { SSSP } 3 \text {. I am rarely bored on this program/ } \\
\text { course }\end{array}$ & 2.05 & 1.26 & 2.04 & 1.231 & 2.06 & 1.313 & 0.902 & 1.97 & 1.240 & 2.20 & 1.286 & 0.207 \\
\hline $\begin{array}{l}\text { SSSP4. I have good friends in this } \\
\text { program/course }\end{array}$ & 3.12 & 1.00 & 3.17 & .960 & 3.03 & 1.081 & 0.312 & 3.02 & 1.061 & 3.30 & .864 & 0.048 \\
\hline SSSP5. My social life is good & 2.75 & 1.29 & 2.83 & 1.288 & 2.59 & 1.273 & 0.184 & 2.71 & 1.306 & 2.82 & 1.251 & 0.557 \\
\hline SSSP6. I seldom feel lonely & 2.48 & 1.26 & 2.43 & 1.301 & 2.56 & 1.191 & 0.451 & 2.48 & 1.194 & 2.47 & 1.390 & 0.977 \\
\hline SSSP7. My accommodation is pleasant & 2.86 & 1.06 & 2.87 & 1.026 & 2.85 & 1.129 & 0.894 & 2.87 & 1.026 & 2.84 & 1.132 & 0.864 \\
\hline Grand total & 129.64 & 31.81 & 129.94 & 29.60 & 129.09 & 35.68 & 0.849 & 125.28 & 28.72 & 137.90 & 35.72 & 0.005 \\
\hline
\end{tabular}

The bold numbers represent the overall scores of the DREEM tool, as per the demographics of the participants.

TABLE 6: Strengths and weaknesses of the program as identified by the DREEM score.

\begin{tabular}{lr}
\hline \multicolumn{2}{c}{ Six best areas of the program identified by high DREEM scores } \\
\hline SASP2. I am confident about passing this year & 3.13 \\
SSSP4. I have good friends in this program/course & 3.12 \\
SPT1. The teachers are knowledgeable & 3.08 \\
SASP8. much of what I have to learn seems relevant to a career in healthcare & 2.95 \\
SPA1. The atmosphere is relaxed during the consultation/PBL sessions & 2.92 \\
SPT2. The teachers espouse a patient-centered approach to teaching & 2.92 \\
Six problem areas of the program identified by low DREEM scores that need to be improved & 2.15 \\
SPL12. The teaching is too teacher-centered & 2.05 \\
SPT3. The teachers ridicule the students & 2.05 \\
SSSP3. I am rarely bored on this program/course & 2.03 \\
SPT9. The teachers get angry in class & 2.01 \\
SPL1. I am encouraged to participate in teaching sessions/class & 1.98 \\
SPA8. I find the experience disappointing & 1.99 \\
\hline
\end{tabular}

TABLE 7: Linear regression analysis of the domain scores with the gender and phase of education.

\begin{tabular}{|c|c|c|c|c|}
\hline Dependent variable & Independent variable & Unadjusted OR & $t$ & $P$ value \\
\hline \multirow{2}{*}{ SPL } & Gender & 0.11 & 1.71 & 0.09 \\
\hline & Phase & 0.20 & 2.96 & $<0.001$ \\
\hline \multirow{2}{*}{ SPT } & Gender & 0.02 & 0.27 & 0.79 \\
\hline & Phase & 0.21 & 3.14 & $<0.001$ \\
\hline \multirow{2}{*}{ SASP } & Gender & -0.05 & -0.68 & 0.50 \\
\hline & Phase & 0.18 & 2.67 & 0.01 \\
\hline \multirow{2}{*}{ SPA } & Gender & -0.05 & -0.70 & 0.49 \\
\hline & Phase & 0.16 & 2.45 & 0.02 \\
\hline \multirow{2}{*}{ SSSP } & Gender & -0.04 & -0.56 & 0.58 \\
\hline & Phase & 0.04 & 0.52 & 0.60 \\
\hline \multirow{2}{*}{ All domains } & Gender & 0.01 & 0.15 & 0.88 \\
\hline & Phase & 0.19 & 2.84 & $<0.001$ \\
\hline
\end{tabular}

The bold numerals represent the statistical significance.

3.8. DREEM Domain Comparisons. Among all of the fifty items of the DREEM survey, six top-scoring items in this study were SASP2, SSSP4, SPT1, SASP8, SPA1, and SPT2 (score range $=3.13-2.92$; Table 6 ); while, the six low-scoring items were SPL12, SPT3, SSSP3, SPT9, SPL1, and SPA8 (score range $=2.15-1.99$; Table 6 ), in order of their decreasing scores, thus making the SASP the best performing subdomain and SPL as the worst (coupled with lowest scores $=62.83 \%$ ) (Figure 1$)$. The regression analysis also reflected that two (SPL and SPT) out of five domains of DREEM differ significantly $(p<0.001)$ in their scores when analyzed based upon the phases of education.

\section{Discussion}

The personal and professional development of medical students' is heavily influenced by EE, in which they spend their learning life. It effectively does affect the students' 
education, their satisfaction with the curriculum, program and course learning outcomes, and their respective professional development [70].

In the current study, we aimed to measure the overall educational environment (EE) in our College of Medicine and tried to analyze the factors such as gender and phase of education which could have an effect on the students' perception towards five domains of the DREEM questionnaire: (a) perception of learning, (b) perception of teachers, (c) academic self-perception, (d) perception of atmosphere, and (e) social self-perception $[6,14]$.

4.1. Overall DREEM Scores. As the overall DREEM score was found to be 129.64 ( $\mathrm{SD}=31.81 ; 64.82 \%)$, which is reflective that students in educational environment within the medicine program is more positive. Numerous studies carried out over the world using the DREEM survey have reported a wide range of overall scores, with the lowest score of 62 (out of 200) in an Australian study [68] to the highest of 149.47 in a report from Ireland [64]. In the Middle Eastern region, the range of overall DREEM scores varies between the lowest of 95.8 in an Iranian study [49] and highest of 130.75 in an Omani report [31]. Furthermore, male and female students had comparable scores with means of 129.9 and 129.1, respectively (Table 4, Figure 2), while phase II and phase III students had significantly different overall scores with means of 125.3 and 137.9, respectively (Table 2). These results are in concordance with the reported results, where it was suggested that senior year students (clinical) tend to score the learning environment higher than the fresher's (basic sciences) $[4,8]$ because of the simple fact that seniors get transitioned to the clinical settings where they are acclimatized well to the specific learning environment.

In the Kingdom of Saudi Arabia, almost two dozen studies have been carried out in different colleges (medicine, nursing, and dental) on a varying sample size with overall DREEM scores ranging 89.9-143.9 (Table 1). The highest overall DREEM score of 143.9, in a sample of 100 nursing students of faculty of applied medical sciences, Umm AlQura University, has been reported by Sayed and El-Sayed [38]. Similarly, a score of 124.90 was reported by Imran et al. [44] in their study on undergraduate medical students on two campuses-Rabigh and Jeddah of King Abdulaziz University. While the lowest overall DREEM score of 89.9 was reported by Al-Ayed et al. [4] in their study on 500 medical students of King Saud University. The results of other important studies across the world are given in Table 1. For our own university, one study carried out on 242 nursing students reported a similar overall DREEM score of 129.70, reflecting the same perception towards EE and curriculum; however, the perception towards the subdomains and especially to each item of the survey differed uniquely. Only three DREEM items in our survey scored above three, i.e., SASP2, SSSP4, and SPT1 (Tables 5 and 6), while only one item scored below two, i.e., SPA8. Most of the items scored in the range of 2.20-3.13, which establishes the facts that the students perceived the curriculum and EE of the College of Medicine as positive. Table 6 provides the identified strong and weak areas of the program as identified by the DREEM score.

4.2. Students' Perception of Learning (SPL). A total score of 30.16 (out of $48 ; 62.83 \%$ ) for this subdomain (Figure 1; Tables 2, 4, and 5) is interpreted as a more positive approach acquired by our program in educational pedagogy; however, this score is the lowest among five subdomains of DREEM and also differed significantly in between phase II and phase III students $(p<0.006)$. The items which scored less in this domain pertained to lack of encouragement in participating in class, teacher-centric teaching, poor use of teaching time, and lack of opportunities for confidence building (scores range 2.01-2.49). Same concerns have been reported by other institutions as well $[2,5,8,16,21,51]$, in which it was reported that students viewed the institutional learning as teacher-centric. Al-Hazimi et al. [71] in their sentinel study had reported that mean DREEM scores for the learning and teaching domains from the innovative (hybrid) programs were significantly higher than the scores from the traditional programs. However, since our program utilized a hybrid curriculum combining traditional lectures with innovative teaching techniques such as problem-based learning (PBL), team-based learning (TBL), flipped classroom, and mini$\mathrm{CeX}$, onus lies on the medical educationist to improve upon the learning environment. The focus should be directed so as to make teaching and learning more student-centric, so as they are encouraged to attend classes proactively in addition to cultivating an environment where students feel selfconfident as well $[5,6,8,16,24,72]$.

4.3. Students' Perception of Teachers (SPT). In this subdomain, a total score of 28.51 (out of $44 ; 64.79 \%$ ) was recorded (Figure 1; Tables 2, 4, and 5), which is interpreted as the teachers moving in the right direction in their pedagogical skills when delivering their sessions of the curriculum in the program. Furthermore, phase II and phase III students had significantly different scores with means of 27.34 and 30.72, respectively (Table 5). One item of this domain pertaining to the teachers' knowledge has a mean score of 3.08 , which is a positive reflecting point of our program, which was in congruence with other positive reports as well $[8,16,21,36,55]$. The items which scored less in this domain pertained to the authoritarianism, anger, and ridicule issues with teachers and students irritating their teachers (scores range 2.03-2.43). Al-Naggar et al. [55] had also reported that two areas of low scores being the teachers being angry in class and students irritating their teachers, and so did other studies as well $[16,36]$. The low scores of this item do suggest that teachers in our program are still inclined towards the traditional authoritarian styles of teaching which identifies a dire need for a well-developed orientation program for faculty. Orienting faculty with specific faculty enhancement activities helps them in developing essential skills, positive attitude, and empathy towards students, which plays a pivotal role in the learning process (WFME, 2005) [6, 12, 69, 70, 72]. Additionally, faculty needs to be encouraged to emphasize self-directed 
learning which is the essence of hybrid curriculum (with PBL and TBL), whereby they need to act as facilitators for the acquisition of necessary knowledge, skills, and attitudes for lifelong learning $[12,16]$. Additionally, harsh criticism and ridicule combined with the negative feedback is one of the most discouraging things teachers can do for their students, reflecting it negatively on their self-confidence $[5,16,36,72]$.

4.4. Students' Academic Self-Perception (SASP). For this subdomain of DREEM, a total score of 21.22 ( $\mathrm{SD}=5.91$; $66.31 \%$ ) was recorded (Figure 1; Tables 2, 4, and 5), which is the best of all domains, thereby, reflecting the facts that students were feeling positive for their overall academic performance (Table 2). The overall score of 21.22 in our study is higher than reported by many other studies $[4,21,36,47]$ but was in congruence with another Saudi study [8], but lesser than reported by an Omani study [31]. Also, phase II and phase III students had significantly different scores with means of 20.49 and 22.60, respectively (Table 5). One item of this domain pertaining to being confident about passing examinations has a mean score of 3.13 , which is the highest score for any item of the DREEM survey in this study. This can be regarded as the strength of our medical program that despite the heavy academic workload, the hybrid curriculum has succeeded in instilling confidence in the student to cope well in EE.

4.5. Students' Perception of Atmosphere (SPA). A total score of $31.35(\mathrm{SD}=8.45 ; 65.31 \%)$ was recorded for this subdomain (Figure 1; Tables 2, 4, and 5), and the total scores based upon phases of education also differed significantly (phase $\mathrm{II}=30.22$ vs. phase $\mathrm{III}=33.50$ ), making it a second best scoring in this study. The scores range for all items were 2.13-2.92, except one related to experience in college being disappointing which had a score of 1.99 (lowest). These scores were comparably higher than reported by other studies $[5,8,16,21,28]$. The high scores of this domain indicate that students have a positive perception of the learning atmosphere in the College of Medicine, which is important as it affects all aspects of the curriculum [72]. The student positively perceived the items related to the program as being well managed, having less problem of cheating, being comfortable socially, and have developed good interpersonal skills. However, we need to look into their experience part holistically so as to improve it further to suit their taste.

4.6. Students' Social Self-Perceptions (SSSP). In this subdomain, a total score of $18.39(\mathrm{SD}=4.84 ; 64.28 \%)$ was recorded (Figure 1; Tables 2, 4, and 5), with no differences in perception based on gender or phases of education, which was a not too bad perception for this subdomain (Table 2). One item related to friendship scored 3.12, which is the second highest scoring item in this study (Tables 5 and 6). The students reported that they were happy with their friends, their social life, not feeling lonely, and a good support system for students in college. These scores were comparably higher than reported by other studies $[5,8,16,21,28]$. Our program has a dedicated and robust academic counseling and mentoring program in place, which provides much-needed counseling and guidance to the students throughout their journey in this college to reduce stress and develop coping techniques.

4.7. DREEM Domain Comparisons. Additionally, we also identified the six-strong and six-weak points in this program (based on their scores) (Table 6). The weak areas are more pertaining to the teachers and their attitudes in the program. So, there is a need for intervention with well-developed strategic actions to improve them in a five-year plan. We do recommend some suggestions such as making attending lectures nonobligatory, evaluating teacher's skills at the end of each session/semester, peer review of teacher's lecturing, obligatory faculty enhancement training/workshops for all teachers, accepting negative feedback from students, and providing grooming training to all teachers to serve as empathetic mentors.

4.8. Limitations of the Study. Although the DREEM questionnaire is one of the best-designed tools to evaluate an EE within any setting, it is not free from all bias like study sample, sample size, study design, and its application itself. Since our study is a cross-sectional study, one of the limitations was that participants of this study varied between gender and phases of education. Second, DREEM items are close-ended and hence cannot capture all the information which a qualitative interview can. Furthermore, the study was carried out during the COVID-19 pandemic via online portal which might affect the overall DREEM and domain scores towards lower quartiles.

\section{Conclusion}

In this study the medical student assessed EE of the medical program, using the DREEM tool, towards a more positive side. However, we did identify a need for improvement in one of the five subdomains of DREEM, i.e., SPT. The perceptions of preclinical students and clinical students about EE differ significantly for four of the five domains of the DREEM questionnaire. One of the strengths of our college was that the overall total DREEM score for EE rated by students came out $129.64(\mathrm{SD}=31.81 ; 64.82 \%)$, with all five subdomains scoring above $60 \%$ and only one of the weak domains of DREEM, i.e., SPT. The domain needs continuous monitoring to analyze various confounding factors which might have affected the perception and also proactive mitigation for future reassessment. In addition, we did find the weak areas within our EE by six low scoring items $(\leq 2.15)$ of DREEM, i.e., SPL12, SPT3, SSSP3, SPT9, SPL1, and SPA8. All of these need an actionable intervention by the academic affairs department for their improvement, with well-developed strategic actions to improve them in a five-year plan, in order to make EE within the college more conducive for teaching and learning. 


\section{Data Availability}

The data used to support this study are included within the article and are available from the corresponding author upon request.

\section{Ethical Approval}

A proper ethical approval as per Helsinki protocol was taken prior to carrying out this study via Institutional Research Board. This study was approved by the Institutional Review Board of King Saud bin Abdulaziz University for Health Sciences (KSAU-HS) and King Abdullah International Medical Research Center (KAIMRC), a research wing of KSAU-HS, Jeddah (reference no. RJ19/137/J; dated: 13/11/ 2019).

\section{Consent}

A due informed consent was taken from every participant.

\section{Conflicts of Interest}

The authors declare that they have no conflicts of interest.

\section{Authors' Contributions}

All authors have critically reviewed and approved the final draft and are responsible for the content and similarity index of the manuscript. SSA conceptualized the project, designed the study, surveyed the existing literature, wrote the entire manuscript, and reviewed thereof in context. MAK statistically analyzed the collected data. MQ, BK, SWS, MM, and AA contributed equally to the data collection and proofread the final manuscript. HAA, ASA, MEH, and OSA contributed to the online dispensation of the survey and collection of data.

\section{Acknowledgments}

The authors would like to express their deep gratitude towards all participating students of the College of Medicine, KSAU-HS, Jeddah campus, who proactively participated in this study.

\section{References}

[1] S. Q. Khan, M. Al-Shahrani, A. Khabeer et al., "Medical students' perception of their educational environment at imam abdulrahman bin faisal university, kingdom of Saudi Arabia," Journal of family \& community medicine, vol. 26, no. 1, pp. 45-50, 2019.

[2] A. Al-Hazimi, A. Al-Hyiani, and S. Roff, "Perceptions of the educational environment of the medical school in king Abdul Aziz university, Saudi Arabia," Medical Teacher, vol. 26, no. 6, pp. 570-573, 2004.

[3] A. M. Alsamarai, A. H. Alobaidi, H. H. Sarhan, F. T. Ismail, and Y. I. Alhamdani, "Assessment of the educational environment at tikrit university college of medicine (TUCOM)," Middle East Journal of Internal Medicine, vol. 6, no. 5, pp. 32-43, 2013.
[4] I. H. Al-Ayed and S. A. Sheik, "Assessment of the educational environment at the college of medicine of king Saud university, riyadh," Eastern Mediterranean Health Journal, vol. 14, no. 4, pp. 953-959, 2008.

[5] T. Aghamolaei and I. Fazel, "Medical students' perceptions of the educational environment at an Iranian Medical Sciences University," BMC Medical Education, vol. 10, no. 1, p. 87, 2010.

[6] S. Roff and S. McAleer, "What is educational climate?" Medical Teacher, vol. 23, no. 4, pp. 333-334, 2001.

[7] M. Armugam, "Relationship between different aspects of health, population and environment education," in Environmental Education Issues and Challenges, M. Rajkumar and A. Selvaraj, Eds., pp. 84-85, Lulu, Raleigh, NC, USA, 1st edition, 2017.

[8] H. Rawas and N. Yasmeen, "Perception of nursing students about their educational environment in college of nursing at king Saud bin Abdulaziz university for health sciences, Saudi Arabia," Medical Teacher, vol. 41, no. 11, pp. 1307-1314, 2019.

[9] S. Farooq, R. Rehman, M. Hussain, and J. M. Dias, "Perceptions of nursing students of educational environment at a private undergraduate School of Nursing in Karachi. JPMA," Journal of the Pakistan Medical Association, vol. 68, no. 2, pp. 216-223, 2018.

[10] S. Sarwar and S. Tarique, "Perception of educational environment: does it impact academic performance of medical students?. JPMA," Journal of the Pakistan Medical Association, vol. 66, no. 10, pp. 1210-1214, 2016.

[11] World Federation for Medical Education (WFME) Report of Executive Council, "International standards in medical education: assessment and accreditation of medical schools' educational programmes. A WFME position paper," Medical Education, vol. 32, no. 5, pp. 549-558, 1998.

[12] "Global standards for Quality Improvement in Medical Education," 2007, http://www.amse-med.eu/wp-content/ uploads/2019/06/2007_medine_global_standards.pdf.

[13] N. Imran, F. Khalid, I. I. Haider et al., "Student's perceptions of educational environment across multiple undergraduate medical institutions in Pakistan using DREEM inventory," JPMA. The Journal of the Pakistan Medical Association, vol. 65, no. 1, pp. 24-28, 2015.

[14] S. Roff, "The Dundee Ready Educational Environment Measure (DREEM)-a generic instrument for measuring students' perceptions of undergraduate health professions curricula," Medical Teacher, vol. 27, no. 4, pp. 322-325, 2005.

[15] R. Varma, E. Tiyagi, and J. K. Gupta, "Determining the quality of educational climate across multiple undergraduate teaching sites using the DREEM inventory," BMC Medical Education, vol. 5, no. 1, p. 8, 2005.

[16] V. Kohli and U. Dhaliwal, "Medical students' perception of the educational environment in a medical college in India: a cross-sectional study using the Dundee Ready Education Environment questionnaire," Journal of educational evaluation for health professions, vol. 10, p. 5, 2013.

[17] S. M. Naser, A. Biswas, M. Nandy, S. Niyogi, G. Biswas, and A. K. Das, "Perception of students regarding educational environment in a medical college in eastern region of India," Journal of the Indian Medical Association, vol. 110, no. 11, pp. 800-806, 2012.

[18] F. Irfan, E. A. Faris, N. A. Maflehi et al., "The learning environment of four undergraduate health professional schools: lessons learned," Pakistan journal of medical sciences, vol. 35, no. 3, pp. 598-604, 2019. 
[19] P. R. Shankar, A. K. Dubey, and R. Balasubramanium, "Students' perception of the learning environment at xavier university school of medicine, Aruba," Journal of educational evaluation for health professions, vol. 10, p. 8, 2013.

[20] H. Bakhshialiabad, G. Bakhshi, Z. Hashemi, A. Bakhshi, and F. Abazari, 'Improving students' learning environment by DREEM: an educational experiment in an Iranian medical sciences university (2011-2016)," BMC Medical Education, vol. 19, no. 1, p. 397, 2019.

[21] N. I. Rahman, A. A. Aziz, Z. Zulkifli et al., "Perceptions of students in different phases of medical education of the educational environment: universiti Sultan Zainal Abidin," Advances in Medical Education and Practice, vol. 6, pp. 211222, 2015.

[22] W. Hongkan, R. Arora, R. Muenpa, and P. Chamnan, "Perception of educational environment among medical students in Thailand," International Journal of Medical Education, vol. 9, pp. 18-23, 2018.

[23] E. Shrestha, R. S. Mehta, G. Mandal, K. Chaudhary, and N. Pradhan, "Perception of the learning environment among the students in a nursing college in Eastern Nepal," BMC Medical Education, vol. 19, no. 1, p. 382, 2019.

[24] S. Roff, S. McAleer, R. M. Harden et al., "Development and validation of the dundee Ready education environment measure (DREEM)," Medical Teacher, vol. 19, no. 4, pp. 295-299, 1997.

[25] Y. Ahmed, M. H. Taha, S. Al-Neel, and A. M. Gaffar, "Students' perception of the learning environment and its relation to their study year and performance in Sudan," International Journal of Medical Education, vol. 9, pp. 145-150, 2018.

[26] K. Salih, M. Idris, O. Elfaki et al., "Measurement of the educational environment in MBBS teaching program, according to DREEM in college of medicine, university of bahri, khartoum, Sudan," Advances in Medical Education and Practice, vol. 9, pp. 617-622, 2018.

[27] A. H. El-Gilany, S. El-Bastawesy, E. El-Sherbeny, and M. Ibrahim, "Undergraduate nursing students' perceptions of educational environment: a national study in Egypt," IOSRJNHS, vol. 6, no. 6, pp. 66-71, 2017.

[28] J. Karim, B. Al-Halabi, Y. Marwan, H. Sadeq, A. Dawas, and D. Al-Abdulrazzaq, "The educational environment of the undergraduate medical curriculum at Kuwait University," Advances in Medical Education and Practice, vol. 6, pp. 297-303, 2015.

[29] S. I. Shehnaz and J. Sreedharan, 'Students' perceptions of educational environment in a medical school experiencing curricular transition in United Arab Emirates," Medical Teacher, vol. 33, no. 1, pp. e37-e42, 2011.

[30] M. Demirören, O. Palaoglu, S. Kemahli, F. Ozyurda, and I. H. Ayhan, "Perceptions of students in different phases of medical education of educational environment: ankara university faculty of medicine," Medical Education Online, vol. 13, p. 8, 2008.

[31] G. P. Prashanth and S. K. Ismail, "The Dundee Ready Education Environment Measure: a prospective comparative study of undergraduate medical students' and interns' perceptions in Oman," Sultan Qaboos University medical journal, vol. 18, no. 2, pp. e173-e181, 2018.

[32] H. J. Sabbagh, H. A. Bakhaider, H. M. Abokhashabah, and M. U. Bader, "Students' perceptions of the educational environment at King Abdulaziz University Faculty of Dentistry (KAUFD): a cross sectional study," BMC Medical Education, vol. 20, no. 1, p. 241, 2020.
[33] S. Al-Natour, "Medical students' perceptions of their educational environment at a Saudi university," Saudi Journal of Medicine and Medical Sciences, vol. 7, no. 3, pp. 163-168, 2019.

[34] A. H. Altemani and T. H. Merghani, "The quality of the educational environment in a medical college in Saudi Arabia," International Journal of Medical Education, vol. 8, pp. 128-132, 2017.

[35] M. Soliman, K. Sattar, S. Alnassar et al., "Medical students' perception of the learning environment at king Saud university medical college, Saudi Arabia, using DREEM inventory," Advances in Medical Education and Practice, vol. 8, pp. 221-227, 2017.

[36] M. H. Al Sheikh, "Educational environment measurement, how is it affected by educational strategy in a Saudi medical school? A multivariate analysis," Journal of Taibah University Medical Sciences, vol. 9, no. 2, pp. 115-122, 2014.

[37] M. A. Mojaddidi, K. I. Khoshhal, F. Habib, S. Shalaby, M. E. El-Bab, and A. H. Al-Zalabani, "Reassessment of the undergraduate educational environment in college of medicine, taibah university, almadinah almunawwarah, Saudi Arabia," Medical Teacher, vol. 35, pp. S39-S46, 2013.

[38] H. Y. Sayed and N. G. El-Sayed, "Students' perceptions of educational environment of the nursing program in faculty of applied medical sciences at Umm Al Qura University," KSA Journal of American Science, vol. 8, no. 4, pp. 69-75, 2012.

[39] A. H. Zawawi and M. Elzubeir, "Using DREEM to compare graduating students' perceptions of learning environments at medical schools adopting contrasting educational strategies," Medical Teacher, vol. 34, 2012.

[40] S. A. Alshehri, A. F. Alshehri, and T. D. Erwin, "Measuring the medical school educational environment: validating an approach from Saudi Arabia," Health Education Journal, vol. 71, no. 5, pp. 553-564, 2012.

[41] T. Hasan and P. Gupta, "Assessing the learning environment at jazan medical school of Saudi Arabia," Medical Teacher, vol. 35, 2013.

[42] A. Al-Mohaimeed, "Perceptions of the educational environment of a new medical school, Saudi Arabia," International Journal of Health Sciences, vol. 7, no. 2, pp. 150-159, 2013.

[43] E. A. AlFaris, N. Naeem, F. Irfan, R. Qureshi, and C. van der Vleuten, "Student centered curricular elements are associated with a healthier educational environment and lower depressive symptoms in medical students," BMC Medical Education, vol. 14, no. 1, p. 192, 2014.

[44] M. Imran, M. S. Shamim, M. Baig, M. Farouq, Z. J. Gazzaz, and O. M. Al-Mutairi, "Tale of two cities: comparison of educational environment of two colleges (Jeddah and Rabigh) affiliated with one university," JPMA. The Journal of the Pakistan Medical Association, vol. 66, no. 3, pp. 316-319, 2016.

[45] O. M. Al Nozha and H. T. Fadel, "Student perception of the educational environment in regular and bridging nursing programs in Saudi Arabia using the Dundee Ready Educational Environment Measure," Annals of Saudi Medicine, vol. 37, no. 3, pp. 225-231, 2017.

[46] S. Al-Saleh, E. M. Al-Madi, B. AlMufleh, and A.-H. AlDegheishem, "Educational environment as perceived by dental students at King Saud University," The Saudi dental journal, vol. 30, no. 3, pp. 240-249, 2018.

[47] M. Bouhaimed, L. Thalib, and S. A. R. Doi, "Perception of the educational environment by medical students undergoing a curricular transition in Kuwait," Medical Principles and Practice, vol. 18, no. 3, pp. 204-208, 2009. 
[48] F. Abusaad, H. E. Mohamed, and A. H. El-Gilany, "Nursing students' perceptions of the educational learning environment in pediatric and maternity courses using DREEM questionnaire," Journal of Education and Practice, vol. 6, pp. 26-32, 2015.

[49] M. M. Andalib, M. M. Malekzadeh, Z. Agharahimi et al., "Evaluation of educational environment for medical students of a tertiary pediatric hospital in tehran, using DREEM questionnaire," Iranian Journal of Pediatrics (Persian edition), vol. 25, no. 5, Article ID e2362, 2015.

[50] B. Hamid, A. Faroukh, and B. Mohammadhosein, "Nursing students' perceptions of their educational environment based on DREEM model in an Iranian university," Malaysian Journal of Medical Sciences: MJMS, vol. 20, no. 4, pp. 56-63, 2013.

[51] A. A. Patil and V. L. Chaudhari, "Students' perception of the educational environment in medical college: a study based on DREEM questionnaire," Korean journal of medical education, vol. 28, no. 3, pp. 281-288, 2016.

[52] S. Bavdekar, S. Save, A. Pillai, and A. M. Kasbe, "DREEM study: students perceptions of learning environment in a medical college in Mumbai, India," Journal of the Association of Physicians of India, vol. 67, no. 4, pp. 50-54, 2019.

[53] D. K. Shah, S. Piryani, R. M. Piryani, M. N. Islam, R. K. Jha, and G. P. Deo, "Medical students' perceptions of their learning environment during clinical years at Chitwan Medical College in Nepal," Advances in Medical Education and Practice, vol. 10, pp. 555-562, 2019.

[54] N. Lai, S. Nalliah, R. C. Jutti, Y. Hla, and V. K. Lim, "The educational environment and self-perceived clinical competence of senior medical students in a Malaysian medical school," Education and Health, vol. 22, no. 2, p. 148, 2009.

[55] R. A. Al-Naggar, M. Abdulghani, M. T. Osman et al., "The Malaysia DREEM: perceptions of medical students about the learning environment in a medical school in Malaysia," Advances in Medical Education and Practice, vol. 5, pp. 177-184, 2014.

[56] J. M. Barcelo, "Medical laboratory science and nursing students' perception of academic learning environment in a Philippine university using Dundee Ready educational environment measure (DREEM)," Journal of Educational Evaluation for Health Professions, vol. 13, p. 33, 2016.

[57] M. T. M. Jiffry, S. McAleer, S. Fernando, and R. B. Marasinghe, "Using the DREEM questionnaire to gather baseline information on an evolving medical school in Sri Lanka," Medical Teacher, vol. 27, no. 4, pp. 348-352, 2005.

[58] Y. Tokuda, E. Goto, J. Otaki et al., "Undergraduate educational environment, perceived preparedness for postgraduate clinical training, and pass rate on the National Medical Licensure Examination in Japan," BMC Medical Education, vol. 10, no. 1, p. 35, 2010.

[59] D.-M. Yoo and D.-H. Kim, "The relationship between students' perception of the educational environment and their subjective happiness," BMC Medical Education, vol. 19, no. 1, p. 409, 2019.

[60] T. Rotthoff, M. S. Ostapczuk, J. De Bruin, U. Decking, M. Schneider, and S. Ritz-Timme, "Assessing the learning environment of a faculty: psychometric validation of the German version of the Dundee Ready education environment measure with students and teachers," Medical Teacher, vol. 33, no. 11, pp. e624-e636, 2011.

[61] U. Jakobsson, N. Danielsen, and G. Edgren, "Psychometric evaluation of the dundee Ready educational environment measure: Swedish version," Medical Teacher, vol. 33, no. 5, pp. e267-e274, 2011.

[62] J. McKendree, "Can we create an equivalent educational experience on a two campus medical school?" Medical Teacher, vol. 31, no. 5, e205 pages, 2009.

[63] S. Miles and S. J. Leinster, "Comparing staff and student perceptions of the student experience at a new medical school," Medical Teacher, vol. 31, no. 6, pp. 539-546, 2009.

[64] D. Bennett, M. Kelly, and S. O’Flynn, “Are the bigger hospitals better: DREEM on?” Irish Journal of Medical Science, vol. 179, no. 4, pp. 515-519, 2010.

[65] J. Palés, A. Gual, J. Escaneroi et al., "Educational climate perception by preclinical and clinical medical students in five Spanish medical schools," International Journal of Medical Education, vol. 6, pp. 65-75, 2015.

[66] H. Till, "Identifying the perceived weaknesses of a new curriculum by means of the dundee Ready education environment measure (DREEM) inventory," Medical Teacher, vol. 26, no. 1, pp. 39-45, 2004.

[67] A. Riquelme, M. Oporto, J. Oporto et al., "Measuring students' perceptions of the educational climate of the new curriculum at the Pontificia Universidad Católica de Chile: performance of the Spanish translation of the Dundee Ready Education Environment Measure (DREEM)," Education and Health, vol. 22, no. 1, p. 112, 2009.

[68] H. Denz-Penhey and J. C. Murdoch, “A comparison between findings from the DREEM questionnaire and that from qualitative interviews," Medical Teacher, vol. 31, no. 10, pp. e449-e453, 2009.

[69] N. Stormon, P. J. Ford, and D. S. Eley, "DREEM-ing of dentistry: Students' perception of the academic learning environment in Australia," European Journal of Dental Education, vol. 23, no. 1, pp. 35-41, 2019.

[70] J. M. Genn, “AMEE Medical Education Guide No. 23 (Part 1): curriculum, environment, climate, quality and change in medical education-a unifying perspective," Medical Teacher, vol. 23, no. 4, pp. 337-344, 2001.

[71] A. Al-Hazimi, R. Zaini, A. Al-Hyiani et al., "Educational environment in traditional and innovative medical schools: a study in four undergraduate medical schools," Education for Health: Change in Learning \& Practice, vol. 17, no. 2, pp. 192-203, 2004.

[72] R. M. Harden, "The learning environment and the curriculum," Medical Teacher, vol. 23, no. 4, pp. 335-336, 2001. 